\title{
PENGARUH METODE DISKUSI DENGAN MODEL PEMBELAJARAN \\ DD-CT (DEEP DIALOGUE-CRITICAL THINKING) DENGAN PEMBERIAN PENGUATAN TERHADAP PRESTASI BELAJAR AKUNTANSI PADA SISWA KELAS XI AKUNTANSI SMKN 1 GEGER MADIUN
}

\author{
Alfi Qurrota A'yuni dan Satrijo Budiwibowo \\ Program Studi Pendidikan Akuntansi - FPIPS \\ IKIP PGRI MADIUN \\ satrijobudiwibowo@yahoo.com
}

\begin{abstract}
ABSTRAK
Tujuan penelitian adalah untuk mengetahui: 1) Apakah metode diskusi dengan model pembelajaran DD-CT (Deep Dialogue-Critical Thinking) dengan pemberian penguatan berpengaruh secara signifikan terhadap prestasi belajar siswa kelas XI Akuntansi SMKN 1 Geger tahun ajaran 2013/2014 pada pokok bahasan menyiapkan pengelolaan kartu aktiva tetap, 2) Apakah metode diskusi dengan model pembelajaran DD-CT (Deep Dialogue- Critical Thinking) tanpa pemberian penguatan berpengaruh secara signifikan terhadap prestasi belajar siswa kelas XI Akuntansi SMKN 1 Geger tahun ajaran 2013/2014 pada pokok bahasan menyiapkan pengelolaan kartu aktiva tetap. Penelitian ini menggunakan metode eksperimen. Populasi penelitian adalah seluruh siswa kelas XI Akuntansi SMK Negeri 1 Geger sejumlah 62 siswa. Penentuan sampel dengan teknik sampling jenuh yaitu penentuan sampelnya sejumlah populasi, 30 siswa kelas XI Akuntansi 1 sebagai kelas eksperimen dan 32 siswa kelas XI Akuntansi 2 sebagai kelas kontrol. Teknik pengumpulan data yang digunakan adalah teknik tes, teknik dokumentasi dan teknik wawancara. Data yang diperoleh dianalisis dengan uji statistik. Hasil uji hipotesis dengan uji-t $(\alpha=0,05)$ menunjukkan bahwa $t_{\text {hitung }}=$ 1,833 dan $t_{\text {tabel }}=1,645$ sehingga $t_{\text {hitung }}>t_{\text {tabel }}$, berdasarkan kriteria maka $\mathrm{H}_{0}$ ditolak. Dengan demikian dapat disimpulan bahwa Metode diskusi dengan model pembelajaran DD-CT (Deep Dialogue-Critical Thinking) dengan pemberian penguatan mempunyai pengaruh yang signifikan terhadap prestasi belajar akuntansi siswa kelas XI Akuntansi SMKN 1 Geger.
\end{abstract}

Kata Kunci: Metode, Diskusi, Model Pembelajaran DD-CT (Deep DialogueCritical Thinking), Pemberian Penguatan, Prestasi belajar akuntansi.

\section{PENDAHULUAN}

Pendidikan merupakan suatu kegiatan yang universal di dalam kehidupan manusia. Dalam Undang- Undang Dasar 1945 pasal 31 ayat 1 termuat bahwa setiap warga Negara berhak mendapatkan pendidikan dan pada ayat 2 disebutkan bahwa setiap warga Negara wajib mengikuti pendidikan dasar dan pemerintah wajib membiayainya. Dan dalam UU No. 20/2003 pasal 5, bahwa setiap warga negara mempunyai hak yang sama untuk memperoleh pendidikan yang bermutu, warga negara yang memiliki kelainan fisik, emosional, mental, intelektual dan atau sosial berhak memperoleh pendidikan khusus, warga negara di daerah terpencil atau terbelakang serta masyarakat adat yang terpencil berhak 
memperoleh pendidikan layanan khusus, warga negara yang memiliki potensi kecerdasan dan bakat istimewa berhak memperoleh pendidikan khusus serta setiap warga negara berhak mendapat kesempatan meningkatkan pendidikan sepanjang hayat.

Akuntansi merupakan salah satu bidang studi yang mempunyai peranan penting dalam dunia pendidikan dan dunia bisnis. Pelajaran akuntansi dalam pelaksanaan pendidikan diberikan pada jenjang pendidikan sekolah menengah atas sampai perguruan tinggi, akan tetapi pelajaran akuntansi diberikan secara kompleks pada sekolah kejuruan dan lebih diutamakan dalam hal praktiknya. Kebanyakan di SMA/SMK proses pembelajarannya cenderung text book oriented dan teacher centered yaitu siswa membuka buku, mendengarkan guru menjelaskan materi, mencatat dan mengerjakan latihan. Sehingga siswa menjadi kurang aktif dalam proses pembelajaran. Seharusnya dalam proses pembelajaran sehari-hari dipusatkan pada siswa (student centered) agar siswa menjadi pribadi yang kritis dan mandiri. Pada mata pelajaran akuntansi, guru memegang peranan penting dalam mewujudkan tercapainya tujuan pembelajaran. Selain menjelaskan konsep dan prinsip, seorang guru akuntansi juga dituntut untuk menciptakan kondisi kelas yang baik agar siswa terlibat secara aktif dalam proses pembelajaran.

Sebagaimana hasil wawancara peneliti dengan guru akuntansi SMKN 1 Geger pada tanggal 03 Maret 2014, bahwa penguasaan siswa terhadap pelajaran akuntansi masih tergolong rendah. Menurut keterangan yang diperoleh dari guru tersebut prestasi belajar siswa masih kurang khususnya pada pelajaran akuntansi. Hal ini disebabkan karena, mayoritas siswa kurang antusias dan kurang aktif selama kegiatan belajar mengajar, sehingga menyebabkan daya serap terhadap materi yang disampaikan guru juga kurang. Sedangkan menurut hasil wawancara peneliti dengan siswa akuntansi SMKN 1 Geger pada tanggal 03 Maret 2014, bahwa penguasaan siswa terhadap pelajaran akuntansi masih tergolong rendah. Menurut keterangan yang diperoleh dari siswa, bahwa mayoritas guru akuntansi masih menggunakan pembelajaran konvensional yaitu penggabungan metode ceramah, tanya jawab dan pemberian tugas sehingga kurang berjalan efektif kurang memotivasi siswa, sehingga prestasi yang dicapai siswa pun kurang memuaskan. Seringkali siswa merasa terpaksa datang dan menghabiskan waktunya di kelas.

Dari hasil wawancara yang dilakukan oleh peneliti dengan guru dan siswa akuntansi, maka dapat diambil kesimpulan bahwa prestasi belajar siswa akuntansi SMKN 1 Geger masih tergolong rendah. Ini terbukti dari hasil ulangan siswa masih banyak yang berada di bawah KKM, yaitu 7,70. Hal ini disebabkan karena mayoritas guru akuntansi menggunakan pembelajaran konvensional sehingga siswa kurang aktif dan kurang tertarik terhadap materi yang disampaikan oleh guru. Hal ini juga menyebabkan kurangnya penguasaan siswa terhadap pelajaran akuntansi.

Dari kondisi di atas, diperlukan suatu metode dan model belajar mengajar yang dapat memberikan penyelesaian terhadap masalah tersebut. Dengan metode dan model pembelajaran ini diharapkan dapat membantu siswa dalam memahami suatu konsep secara utuh dan benar. Untuk itulah diperlukan strategi pembelajaran yang lebih memberdayakan siswa. Sebuah strategi pembelajaran yang tidak mengharuskan siswa menghafal fakta- fakta, tetapi sebuah strategi yang 
mendorong siswa untuk aktif dan menemukan sendiri. Selain metode dan model pembelajaran, yang harus diperhatikan oleh guru adalah bagaimana cara memotivasi siswa dan membangkitkan semangat siswa untuk belajar, salah satu caranya adalah dengan memberikan penguatan kepada siswa baik dalam bentuk penguatan verbal, maupun nonverbal yang merupakan bagian dari modofikasi tingkah laku guru terhadap tingkah laku siswa yang bertujuan untuk memberikan informasi atau umpan balik (feedback) bagi siswa atas perbuatan yang baik sebagai suatu tindakan dorongan bagi siswa atas perbuatan yang baik sebagai suatu tindakan dorongan sehingga perbuatan tersebut terus diulang (Rusman, 2013: 84).

Anak yang punya kemampuan menyerap pelajaran dengan cepat mendapat reward dan pujian, sedangkan anak yang lambat biasanya mendapat hukuman atau teguran (Erwin Sujanto, 2011: 9). Metode diskusi yang dikombinasikan dengan model pembelajaran DD-CT dengan pemberian penguatan merupakan model pembelajaran yang membantu guru untuk menjadikan pembelajaran bermakna bagi siswa. Model Pembelajaran ini mampu meningkatkan minat, motivasi dan keaktifan siswa. Fokus kajian pendekatan DD-CT dalam pembelajaran yaitu dikonsentrasikan dalam mendapatkan pengetahuan dan pengalaman, melalui dialog secara mendalam dan berpikir kritis, tidak saja menekankan keaktifan siswa pada aspek fisik, akan tetapi juga aspek intelektual, sosial, mental, emosional dan spiritual. Pembelajaran DD-CT dapat dijadikan sebagai pendekatan pembelajaran alternatif, dimana melalui DD-CT siswa belajar melalui "mengalami, merasakan, rnendialogkan bukan hanya menghafalkan".

Metode dan model mengajar yang mampu menarik serta mampu membangkitkan semangat dan keaktifan siswa untuk belajar tentunya akan mempengaruhi prestasi belajar siswa semakin tinggi tingkat ketertarikan siswa untuk belajar akan membangkitkan aktivitas siswa dengan bidang studi akuntansi. Demikian juga dengan semakin banyak pula yang akan siswa pahami sehingga dapat meningkatkan prestasi belajarnya.

\section{TELAAH PUSTAKA}

Menurut Rusman (2013: 84) penguatan adalah respon terhadap suatu tingkah laku yang dapat meningkatkan kemungkinan berulangnya kembali tingkah laku tersebut. Hamdani (2011: 159) yang menyatakan bahwa metode diskusi merupakan interaksi antarsiswa atau interaksi siswa dengan guru, untuk menganalisis, memecahkan masalah, menggali, atau memperdebatkan topik atau permasalahan tertentu. Hamdani (2011: 147), model adalah kerangka konseptual yang digunakan sebagai pedoman atau acuan dalam melakukan sebuah kegiatan. Trianto (2010: 17), menyebutkan bahwa pembelajaran merupakan interaksi dua arah dari seorang guru dan peserta didik, di mana diantara keduanya terjadi komunikasi (transfer) yang intens dan terarah menuju pada suatu target yang telah ditetapkan sebelumnya. Sedangkan Aulya Nanda et al, (2013: 287) berpendapat bahwa Deep Dialogue berupa diskusi bermakna bukan hanya dialog satu arah sehingga proses pembelajaran dapat lebih efektif karena dapat saling membantu, bertukar informasi, dan mengkoreksi agar diperoleh pemahaman yang merata. Sedangkan Critical Thinking atau berpikir kritis diperlukan setiap siswa dalam memahami maksud dan konsep dari bacaan sesuai kemampuannya dengan 
mempertahankan hasil pemikiran atau menerima kritikan dan pendapat orang lain dalam memahami konsep atau menyelesaikan permasalahan.

American Accounting Association (dalam Soemarso, 2004: 3), berpendapat bahwa akuntansi adalah proses mengidentifikasikan, mengukur, dan melaporkan informasi ekonomi, untuk memungkinkan adanya penilaian dan keputusan yang jelas dan tegas bagi mereka yang menggunakan informasi tersebut. Hamdani (2011: 137), berpendapat bahwa prestasi adalah hasil dari suatu kegiatan yang telah dikerjakan, diciptakan, baik secara individual maupun kelompok. M. Dalyono (2009: 208), merumuskan bahwa belajar adalah usaha menyesuaikan diri terhadap kondisi- kondisi atau situasi-situasi disekitar kita. Menurut Hamdani (2011: 138), prestasi belajar adalah hasil pengukuran dari penilaian usaha belajar yang dinyatakan dalam bentuk simbol, huruf maupun kalimat yang menceritakan hasil yang sudah dicapai oleh setiap anak pada periode tertentu. Prestasi belajar akuntansi yang diteliti dalam penelitian ini, datanya diambil dari tes formatif pokok bahasan kartu aktiva tetap setelah pembelajaran menggunakan metode diskusi dengan model pembelajaran DD-CT (Deep Dialogue-Critical Thinking) dengan pemberian penguatan dan metode diskusi dengan model pembelajaran DD-CT (Deep Dialogue- Critical Thinking) tanpa pemberian penguatan. Tujuan yang ingin dicapai dalam penelitian ini adalah untuk mengetahui apakah terdapat pengaruh yang signifikan antara metode diskusi dengan model pembelajaran DD-CT (Deep Dialogue-Critical Thinking) dengan pemberian penguatan terhadap prestasi belajar siswa kelas XI Akuntansi SMKN 1 Geger tahun ajaran 2013/2014 pada pokok bahasan menyiapkan pengelolaan kartu aktiva tetap. Untuk mengetahui apakah terdapat pengaruh yang signifikan antara metode diskusi dengan model pembelajaran DD-CT (Deep Dialogue-Critical Thinking) tanpa pemberian penguatan terhadap prestasi belajar siswa kelas XI Akuntansi SMKN 1 Geger tahun ajaran 2013/2014 pada pokok bahasan menyiapkan pengelolaan kartu aktiva tetap.

\section{DESAIN PENELITIAN}

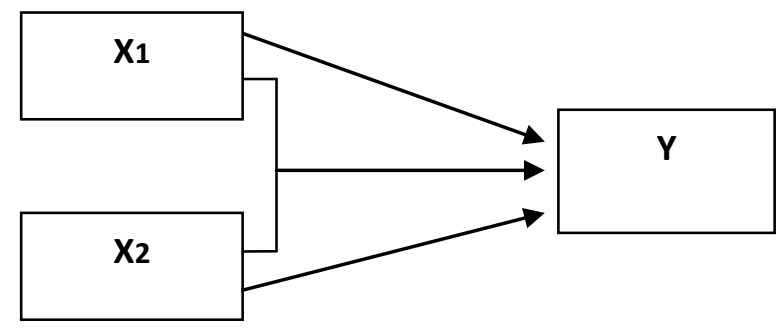

Keterangan:

X1: Metode diskusi dengan model pembelajara DD-CT dengan pemberian penguatan.

X2: Metode diskusi dengan model pembelajaran DD - CT dengan tanpa penguatan

Y : Prestasi belajar

\section{HIPOTESIS PENELITIAN}

H1 : Terdapat pengaruh yang signifikan antara metode diskusi dengan model pembelajaran DD-CT (Deep Dialogue-Critical Thinking) dengan penguatan 
terhadap prestasi belajar siswa kelas XI Akuntansi SMKN 1 Geger tahun ajaran 2013/2014 pada pokok bahasan mendiskripsikan pengelolaan kartu aktiva tetap.

\section{METODE PENELITIAN}

Untuk mengetahui metode dan model pembelajaran manakah yang berpengaruh secara signifikan terhadap prestasi belajar akuntansi yang diajar dengan menggunakan metode diskusi dengan model pembelajaran DD-CT (Deep Dialogue-Critical Thinking) dengan pemberian penguatan dan yang diajar dengan metode diskusi dengan model pembelajaran DD-CT (Deep Dialogue-Critical Thinking) tanpa pemberian penguatan digunakan metode eksperimen. Populasi pada penelitian ini adalah seluruh siswa kelas XI Akuntansi SMKN 1 Geger, yang terdiri dari 30 siswa kelas XI Akuntansi 1 dan 32 siswa kelas XI Akuntansi 2. Pengambilan sampel menggunakan teknik sampling jenuh. Berdasarkan hasil dari sampling jenuh, sampel pada penelitian ini adalah siswa kelas XI Akuntansi 1 sebagai kelas eksperimen dan siswa kelas XI Akuntansi 2 sebagai kelas kontrol.

\section{HASIL PENELITIAN}

Uji coba instrumen dilakukan pada kelas XI Akuntansi SMKN 1 Geger dengan jumlah 30 siswa. Instrumen yang diuji coba berupa soal akuntansi dengan jumlah 20 soal berbentuk pilihan ganda. Uji coba instrumen meliputi validitas, reliabilitas, daya pembeda, dan tingkat kesukaran. Dari hasil uji instrumen soal tes uji coba diperoleh 4 soal tidak valid karena koefisiennya korelasinya $<0,30$, dan 16 soal valid karena koefisien korelasinya $>0,30 . r_{11}=0,71$ ini berarti dikatakan reliable karena $r_{11}>0,70$. Berdasarkan hasil analisis tes uji coba taraf kesukaran diperoleh bahwa soal dengan kriteria mudah berjumlah 8 soal dengan $\mathrm{P} 0,71$ sampai 1,00 . Soal dengan kriteria sedang berjumlah 11 soal dengan $\mathrm{P} 0,31$ sampai 0,70 . Soal dengan kriteria sulit berjumlah 1 soal dengan $P \quad 0,00$ sampai 0,30 . Sedangkan berdasarkan uji daya pembeda diperoleh 4 soal yang indeks diskriminasinya kurang dari 0,4 dan klasifikasinya jelek. Adapun hasil uji instrumen soal tes dapat dilihat dalam tabel berikut:

Tabel 1 Hasil Analisis Instrumen Soal Tes Uji Coba

\begin{tabular}{|c|c|c|c|c|c|}
\hline $\begin{array}{l}\text { No. } \\
\text { Soal }\end{array}$ & Validitas & $\begin{array}{l}\text { Tingkat } \\
\text { Kesukaran }\end{array}$ & $\begin{array}{l}\text { Daya } \\
\text { Pembeda } \\
\end{array}$ & Reliabilitas & Kesimpulan \\
\hline 1 & Valid & Sedang & Baik & \multirow{13}{*}{ Reliabel } & Digunakan \\
\hline 2 & Valid & Mudah & Cukup & & Digunakan \\
\hline 3 & Valid & Mudah & Baik & & Digunakan \\
\hline 4 & Valid & Mudah & Cukup & & Digunakan \\
\hline 5 & Valid & Sedang & Baik & & Digunakan \\
\hline 6 & $\begin{array}{l}\text { Tidak } \\
\text { Valid }\end{array}$ & Sedang & Baik & & $\begin{array}{l}\text { Tidak } \\
\text { Digunakan }\end{array}$ \\
\hline 7 & Valid & Mudah & Cukup & & Digunakan \\
\hline 8 & Valid & Sedang & Baik & & Digunakan \\
\hline 9 & $\begin{array}{l}\text { Tidak } \\
\text { Valid }\end{array}$ & Mudah & Jelek & & $\begin{array}{l}\text { Tidak } \\
\text { Digunakan }\end{array}$ \\
\hline 10 & Valid & Sedang & Baik & & Digunakan \\
\hline 11 & Valid & Sukar & Jelek & & Digunakan \\
\hline 12 & Valid & Sedang & Baik & & Digunakan \\
\hline 13 & Valid & Mudah & Baik & & Digunakan \\
\hline
\end{tabular}




\begin{tabular}{|c|c|c|c|c|}
\hline 14 & Valid & Sedang & Cukup & Digunakan \\
\hline 15 & Valid & Sedang & Cukup & Digunakan \\
\hline 16 & Valid & Sedang & Cukup & Digunakan \\
\hline 17 & $\begin{array}{l}\text { Tidak } \\
\text { Valid }\end{array}$ & Mudah & Jelek & $\begin{array}{l}\text { Tidak } \\
\text { Digunakan }\end{array}$ \\
\hline 18 & $\begin{array}{l}\text { Tidak } \\
\text { Valid }\end{array}$ & Mudah & Jelek & $\begin{array}{l}\text { Tidak } \\
\text { Digunakan }\end{array}$ \\
\hline 19 & Valid & Sedang & Cukup & Digunakan \\
\hline 20 & Valid & Sedang & Cukup & Digunakan \\
\hline
\end{tabular}

Sesuai uji validitas, reliabilitas, taraf kesukaran, dan daya pembeda pada soal tes uji coba di atas diperoleh bahwa 16 soal telah memenuhi persyaratan sebagai instrumen penelitian yang baik dan 4 soal tidak memenuhi persyaratan sebagai instrumen yang baik. Ini berarti 16 soal tes formatif sudah memenuhi persyaratan sebagai instrumen penelitian yang baik serta instrumen tes akuntansi dapat digunakan untuk mengambil data prestasi belajar akuntansi pokok bahasan kartu aktiva tetap.

Uji keseimbangan yang digunakan adalah uji-t dengan prasyarat populasi normal dan sampel homogen. Adapun hasil uji keseimbangan dan uji prasyarat dapat dilihat dalam tabel berikut:

Tabel 2 Hasil Uji Pendahuluan dan Uji Keseimbangan

\begin{tabular}{|c|c|c|c|}
\hline Kelas & Uji Normalitas & Uji Homogenitas & Uji Keseimbangan \\
\hline Eksperimen & $\begin{array}{l}L_{o b s}=0,135 \\
L_{0,05 ; 30}=0,161 \\
\text { DK: }\{\mathrm{L} \mid \mathrm{L}>0,161\} \\
L_{\text {hitung }} \leq L_{\text {tabel }} \\
H_{l} \text { Diterima }\end{array}$ & $\begin{array}{l}F_{o b s}=0,62 \\
\mathrm{DK}=\{F \mid F>1,84\}\end{array}$ & $\begin{array}{l}t_{o b s}=3,35 \\
t_{0.05 ; 62}=1.645 \\
\mathrm{DK}=\{\mathrm{t} \mid \mathrm{t}>1.645\}\end{array}$ \\
\hline Kontrol & $\begin{array}{l}L_{o b s}=0,094 \\
L_{0,05 ; 32}=0,157 \\
\text { DK: }\{\mathrm{L} \mid \mathrm{L}>0,157\} \\
L_{\text {hitung }} \leq L_{\text {tabel }} \\
H_{l} \text { Diterima }\end{array}$ & $\begin{array}{l}\text { Fhitung }<\text { Ftabel } \\
H_{l} \text { Diterima }\end{array}$ & $\begin{array}{l}t_{\text {hitung }}>t_{\text {tabel }} \\
H_{l} \text { Diterima }\end{array}$ \\
\hline Kesimpulan & $\begin{array}{l}\text { Sampel berasal dari } \\
\text { populasi } \\
\text { berdistribusi normal }\end{array}$ & $\begin{array}{l}\text { Variansi sampel } \\
\text { homogen }\end{array}$ & $\begin{array}{l}\text { Siswa kelas } \\
\text { eksperimen dan kelas } \\
\text { kontrol mempunyai } \\
\text { kemampuan sama }\end{array}$ \\
\hline
\end{tabular}

Data hasil tes prestasi belajar akuntansi siswa kelas XI Akuntansi 1 dan kelas XI Akuntansi 2 berupa nilai dari tes tersebut. Data kemudian dianalisis untuk dilakukan uji hipotesis. Nilai rata-rata siswa kelas XI Akuntansi 1 yang diajar dengan metode diskusi dengan model pembelajaran DD-CT (Deep Dialogue-Critical Thinking) dengan pemberian penguatan adalah 79, 57 dengan standar deviasi 12.02779. Sedangkan nilai rata-rata siswa kelas XI Akuntansi 2 yang diajar dengan metode diskusi dengan model pembelajaran DD-CT (Deep Dialogue- Critical Thinking) tanpa pemberian penguatan adalah 73,5 dengan standar deviasi 15.24213. 
Pada penelitian ini, uji yang digunakan untuk menguji hipotesis adalah uji t. Hipotesisnya adalah sebagai berikut:

a. $\mathrm{H}_{0}: \mu_{1} \leq \mu_{2}$

Artinya prestasi belajar siswa yang pembelajarannya menggunakan metode diskusi dengan model pembelajaran DD-CT (Deep Dialogue-Critical Thinking) dengan pemberian penguatan tidak mempunyai pengaruh yang signifikan dibandingkan dengan menggunakan metode diskusi dengan model pembelajaran DD-CT (Deep Dialogue - Critical Thinking) tanpa pemberian penguatan.

b. $\mathrm{H}_{1}: \mu_{1}>\mu_{2}$

Artinya prestasi belajar siswa yang pembelajarannya menggunakan metode diskusi dengan model pembelajaran DD-CT (Deep Dialogue-Critical Thinking) dengan pemberian penguatan mempunyai pengaruh yang signifikan dibandingkan dengan menggunakan metode diskusi dengan model pembelajaran DD-CT (Deep Dialogue - Critical Thinking) tanpa pemberian penguatan.

Kriteria ujinya adalah $\mathrm{H}_{1}$ diterima jika $t_{\text {hitung }}>t_{\text {tabel }}$ dan $\mathrm{H}_{0}$ ditolak jika $t_{\text {hitung }}<t_{\text {tabel }}$. Dari hasil analisis data uji hipotesis diperoleh $t_{\mathrm{obs}}=1,883$ dan $\mathrm{DK}=\{t \mid t>1,645\}$. Ini berarti $\mathrm{H}_{0}$ ditolak karena $t_{\text {hitung }}>t_{\text {tabel }}$, sehingga dapat disimpulkan bahwa prestasi belajar akuntansi yang diajar dengan metode diskusi dengan model pembelajaran DD-CT (Deep Dialogue - Critical Thinking) dengan pemberian penguatan mempunyai pengaruh yang signifikan dibandingkan dengan menggunakan metode diskusi dengan model pembelajaran DD-CT (Deep Dialogue - Critical Thinking) tanpa pemberian penguatan.

\section{PEMBAHASAN}

Pembelajaran dengan menggunakan metode diskusi dengan model pembelajaran DD-CT (Deep Dialogue-Critical Thingking) dengan pemberian penguatan adalah pembelajaran terpusat pada siswa. Siswa dapat belajar aktif, kreatif dan berfikir kritis dalam memecahkan suatu persoalan. Pada model ini, guru tidak menjelaskan materi secara penuh melainkan siswa diberikan suatu konteks persoalan nantinya siswa akan menyelesaikan sendiri maupun diskusi yang kemudian disampaikan kepada teman sekelas. Diharapkan siswa untuk aktif mempelajari dan memahami materi secara mandiri terlebih dahulu. Selain itu guru juga memberikan penguatan kepada siswa agar termotivasi yang akhirnya akan mendorong siswa untuk terbiasa bertanya dan menanggapi tentang sesuatu hal. Penelitian ini bertujuan untuk mengkaji perbedaan prestasi belajar siswa menggunakan metode diskusi dengan model pembelajaran DD-CT (Deep Dialogue-Critical Thingking) dengan pemberian penguatan dan menggunakan metode diskusi dengan model pembelajaran DD-CT (Deep Dialogue-Critical Thingking) dengan tanpa penguatan.

Hasil post- test setelah diberi perlakuan yang berbeda dalam pembelajaran pada materi persiapan pengelolaan kartu aktiva tetap , diperoleh prestasi belajar yang berbeda, yakni kelas eksperimen dengan rata- rata 79,57 sedangkan kelas kontrol dengan rata- rata 73,5 . Hasil analisa data menunjukkan bahwa pada 
pembelajaran terdapat perbedaan yang signifikan antara prestasi belajar siswa yang menggunakan metode diskusi dengan model pembelajaran DD-CT (Deep Dialogue-Critical Thingking) dengan penguatan dan pembelajaran yang menggunakan metode diskusi dengan model pembelajaran DD-CT (Deep Dialogue-Critical Thingking) tanpa penguatan. Perbedaan prestasi belajar siswa ini dikarenakan pada kelas eksperimen siswa lebih aktif dibandingkan dengan kelas kontrol. Pada kelas eksperimen, pembelajaran menggunakan metode diskusi dengan model pembelajaran DD-CT (Deep Dialogue-Critical Thingking) dengan penguatan, guru memberikan hadiah kepada siswa yang berani bertanya ataupun menanggapi tentang suatu permasalahan, sehingga mendorong siswa berfikir baik secara individu untuk memprediksi jawabannya sendiri maupun dalam berdiskusi kelompok untuk berinteraksi secara mendalam dan mendorong siswa untuk berfikir kritis dalam memperoleh prediksi jawaban yang paling tepat agar mendapatkan hadiah. Selain itu dalam proses pembelajaran hampir semua siswa ingin bertanya maupun menanggapi tentang permasalahan yang ada dalam materi. Hal ini akan mempengaruhi daya serap siswa dalam menerima materi, karena jika siswa belajar dengan membaca, mendengarkan dan berbicara maka prosentase pemahaman siswa akan lebih tinggi dibandingkan dengan hanya membaca atau mendengarkan saja.

Sedangkan pada kelas kontrol, pembelajaran menggunakan metode diskusi dengan model pembelajaran DD-CT (Deep Dialogue-Critical Thingking) tanpa penguatan, guru tidak memberikan suatu hadiah kepada siswa, baik yang bertanya maupun yang menanggapi. Jadi tingkat motivasinya rendah sehingga menyebabkan siswa kurang maksimal dalam berdiskusi. Selain itu hanya sebagian siswa yang ingin bertanya maupun menanggapi. Penelitian sebelumnya menunjukkan bahwa melalui penerapan model pembelajaran berbasis DDCT dapat mengoptimalkan semua potensi yang dimiliki oleh siswa untuk mencari, menemukan, mengkonstruk, dan mengkomunikasikan hasil temuannya dalam bentuk lisan dan tulis dengan lebih baik (Salamah: 2008). Hasil penelitian sebelumnya tersebut menguatkan bahwa hasil belajar dengan menggunakan model pembelajaran Cooperative Integrated Reading and Composition berbasis Deep Dialogue-Critical Thinking lebih baik daripada di kelas kontrol serta dalam proses pembelajarannya siswa akan sangat aktif.

Guru bidang studi menilai metode diskusi dengan model pembelajaran DD-CT (Deep Dialogue-Critical Thinking) dengan pemberian penguatan baik untuk diterapkan dan dapat mendukung untuk tercapainya prestasi belajar akuntansi yang lebih baik. Menurut siswa metode diskusi dengan model pembelajaran DD-CT (Deep Dialogue-Critical Thinking) dengan pemberian penguatan lebih menarik sehingga siswa lebih termotivasi dalam mengikuti pembelajaran daripada model pembelajaran yang biasa diterapkan di sekolah. Hal ini karena mereka dituntut untuk lebih aktif, siswa diberi kesempatan mengungkapkan pendapatnya tanpa rasa malu pada teman sendiri dalam kelompoknya, siswa lebih paham karena menemukan konsep dengan bahasa mereka sendiri, dan siswa yang pasif akan menjadi aktif dengan belajar secara kelompok.

Proses pembelajaran dengan menggunakan metode diskusi dengan model pembelajaran DD-CT (Deep Dialogue-Critical Thinking) dengan pemberian penguatan memiliki beberapa kendala dan kekurangan, yakni memotivasi kembali 
siswa dalam melakukan model pembelajaran yang sama setiap pertemuannya dan kurangnya manajemen waktu yang baik oleh siswa dalam berdiskusi. Selain itu, dalam setiap pembelajaran harus benar-benar menekankan pada siswa untuk terlebih dahulu memprediksi jawabannya sendiri kemudian didiskusikan secara mendalam dengan kelompoknya. Solusinya guru harus membangun suasana santai namun serius agar siswa tidak merasa jenuh, selalu mengingatkan tentang penggunaan waktu yang efisien, dan menegaskan pada siswa. Kemudian perlu menekankan peran guru dalam pengelolaan kelas yang efektif agar tercipta keseriusan dan kedisiplinan siswa.

\section{KESIMPULAN}

Temuan dari penelitian ini adalah metode diskusi dengan model pembelajaran DD-CT (Deep Dialogue-Critical Thinking) dengan pemberian penguatan pada pembelajaran akuntansi membuat siswa termotivasi dan mampu meningkatkan aktivitas siswa selama pembelajaran dan mempengaruhi prestasi belajar siswa secara signifikan. Pembahasan di atas menunjukkan bahwa pembelajaran akuntansi dengan menggunakan metode diskusi dengan model pembelajaran DD-CT (Deep Dialogue-Critical Thinking) dengan pemberian penguatan dapat digunakan sebagai informasi dan alternatif pembelajaran untuk mengajar akuntansi serta memperbaiki prestasi belajar siswa. Dengan menggunakan metode diskusi dengan model pembelajaran DD-CT (Deep Dialogue-Critical Thinking) siswa menjadi lebih aktif dan kemampuan siswa untuk mengingat materi yang telah dipelajari lebih baik dan bermakna. Sehingga meningkatkan daya serap siswa dalam menerima materi, selain itu prestasi belajar siswa juga mengalami peningkatan.

\section{DAFTAR PUSTAKA}

Agus Suprijono. 2011. Cooperative Learning. Yogyakarta: Pustaka Pelajar.

Aulya Nanda dkk. 2013. Penerapan Model Pembelajaran Cooperative Integrated Reading and Composition (CIRL) Berbasis Deep Dialogue Critical Thinking (DDCT) Dalam Pembelajaran Fisika di SMP. Jurnal Pendidikan Fisika (Online),Vol.2, No.3,(http://library.unej.Ac.id/client/en_US/default/search/asset/1112;jse ssionid=6E9B613F5A26AB41EE2DECAD59087574?qu=SRI+HASTU TI\&amp;ps=300. Diunduh 20 Februari 2014).

Budiyono. 2004. Statistik Untuk Penelitian. Surakarta: Universitas Sebelas Maret Dalyono, M. 2009. Psikologi Pendidikan. Jakarta: Rineka Cipta.

Darmadi. 2009. Pengaruh Pemanfaatan Powerpoint Dalam Pembelajaran Terhadap Prestasi Belajar Matematika Tingkat Sekolah Dasar Ditinjau Dari Gaya Belajar Siswa. Jurnal Pendidikan. Vol.15, No.2: 99-112.

Dewi Salma Prawiradilaga. 2008. Prinsip Desain Pembelajaran. Jakarta: Kencana.

Erwin Sujanto. 2011. Sukses Belajar dan Mengajar Dengan teknik Memori. Jakarta: Gramedia Pustaka Utama.

Hamdani. 2011. Strategi Balajar Mengajar. Bandung: Pustaka Setia.

Hamzah. 2012. Model Pembelajaran. Jakarta: Bumi Aksara.

Ibrahim, R dan Nana Syaodih . 2010. Perencanaan Pengajaran. Jakarta: Rineka Cipta.

Isjoni, H. 2011. Pembelajaran Kooperatif. Yogyakarta: Pustaka Pelajar. 
Jonathan Sarwono. 2006. Metode Penelitian Kuantitatif dan Kualitatif. Yogyakarta: Graha Ilmu.

Ngalim Purwanto, M. 2010. Psikologi Pendidikan. Bandung: Remaja Rosdakarya. Reni Akbar Hawadi. 2004. Akselerasi. Jakarta: Grasindo.

Rusman. 2013. Model- Model Pembelajaran. Jakarta: Rajagrafindo Persada.

Soemarso. 2004. Akuntansi Suatu Pengantar. Jakarta: Salemba Empat.

Sugiyono. 2013. Cara Mudah Menyusun: Skripsi, Tesis, dan Disertasi. Bandung: Alfabeta Bandung.

Supri Wahyudi Utomo. 2012. Pengaruh Nilai Perencanann Pengajaran dan Nilai Mikro Teaching Terhadap Nilai PPL Mahasiswa Pendidikan Akuntansi IKIP PGRI MADIUN. Jurnal Akuntansi dan Pendidikan. Vol. 1, No.2: 56- 65.

Syaiful Bahri Dan Aswan Zain. 2010. Strategi BelajarMengajar. Jakarta: Rineka Cipta.

Suharsimi Arikunto. 2010. Prosedur Penelitian. Jakarta: Rineka Cipta. .2013. Manajemen Penelitian.Jakarta: Rineka Cipta . 2012. Dasar-Dasar Evaluasi Pendidikan. Jakarta: Bumi Aksara.

Trianto. 2010. Mendesain Model Pembelajaran Inovatif- Progresif. Jakarta: Kencana. 